\title{
The Largest Cystic Nephroma Treated by Laparoscopic Nephron- sparing Surgery: A Case Report and Review of the Literature
}

\section{Laparoskopik Nefron Koruyucu Cerrahi ile Tedavi Edilen En Büyük Kistik Nefroma Olgusu: Olgu Sunumu Eşliğinde Literatürün Gözden Geçirilmesi}

\author{
(D) Nejdet Karşıyakalı1 , (D) Uğur Yücetaş ${ }^{1}$, (D) Hüseyin Aytaç Ateş4 ${ }^{4}$, (D) Sevim Baykal Koca ${ }^{2}$, (D) Ceyda Turan Bektaş3, \\ (D) Mahmut Gökhan Toktaş1 \\ 1 istanbul Training and Research Hospital, Clinic of Urology, Istanbul, Turkiye \\ 2 istanbul Training and Research Hospital, Clinic of Pathology, Istanbul, Turkiye \\ 3 Istanbul Training and Research Hospital, Clinic of Radiology, Istanbul, Turkiye \\ 4Siirt State Hospital, Clinic of Urology, Siirt, Turkiye
}

\section{Abstract}

Cystic nephroma is a rare benign tumour of the kidney. The symptoms are often non-specific and the diagnosis of the disease is usually made incidentally. Definitive diagnosis can be possible with histopathological evaluation. Surgical resection provides curative treatment. We report a successful removal of cystic nephroma in a 67-year-old female which was managed by laparoscopic nephron-sparing surgery. When a renal mass including multiple cystic formations is visualized on radiological imaging, the clinician should consider cystic nephroma for differential diagnosis, and these cases should be evaluated in terms of nephron-sparing surgery.

Keywords: Cystic nephroma, Laparoscopy, Partial nephrectomy, Renal cyst, Renal tumour

$\ddot{0 z z}$

Kistik nefroma böbreğin nadir görülen iyi huylu bir tümörüdür. Semptomlar sıklıkla özellikli değildir ve tanı genellikle rastlantısal olarak konulmaktadır. Kesin tanı histopatolojik değerlendirme sonrasında mümkündür. Cerrahi rezeksiyon küratif tedavi yaklaşımı sağlar. Laparoskopik nefron koruyucu cerrahi ile başarılı bir şekilde tedavi ettiğimiz 67 yaşındaki kadın hastada kistik nefroma olgusunu sunduk. Radyolojik görüntülemede çok sayıda kistik yapı içeren bir renal kitle saptandığında klinisyen ayırıcı tanıda kistik nefromayı göz önünde bulundurmalı ve bu olgular nefron koruyucu cerrahi açısından değerlendirilmelidir.

Anahtar Kelimeler: Kistik nefroma, Laparoskopi, Parsiyel nefrektomi, Renal kist, Renal tümör

\section{Introduction}

Cystic nephroma is a mixed mesenchymal and epithelial neoplasm of the kidney which has a benign nature and tends to grow slowly (1). Despite the increased prevalence in children aged between 3 months and 2 years and in middle-aged adults (40-70), the prevalence has been reported to be $2.4 \%$ in the literature (2).

After being described by Edmunds first as cystic nephroma (3), various descriptions, such as "multilocular cystic tumor", "renal multilocular cyst", "multilocular cystic nephroma", "renal cystic hamartoma", "partial polycystic kidney" and "polycystic nephroma", have been made in the literature (4). Some authors have argued that cystic nephroma was closely related with mixed epithelial and stromal tumors (MESTs) and even they might be the same clinical entity. The World Health Organization and the International Society of Urological Pathology Vancouver classifications collect these clinical entities under the same title $(5,6)$. 


\section{Case Presentation}

Written informed consent was obtained from patient who participated. A 67-year-old female patient was admitted to the urology outpatient clinic in November 2017 with the complaints of painless, unclotted hematuria and left lateral pain. She had a history of medical treatment due to hypertension and type 2 diabetes mellitus. The complete blood count, liver function, renal function and coagulation tests were found to be within the normal limits. On ultrasound imaging, a cystic mass was identified in the left kidney. On the dynamic magnetic resonance

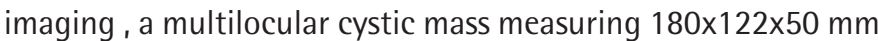
in size, showing an exophytic extension from the middle-lower pole was identified. Multiple septae were visualized in the mass; some of them were thick and irregular and showed contrast uptake. The cystic mass was graded as Bosniak category 3 (Figure 1). The patient underwent non-ischemic left laparoscopic partial nephrectomy operation in December 2017. Macroscopic view of the mass in the operating room after the excision is shown in Figure 2.

On pathological examination, macroscopic evaluation demonstrated a mass without solid area. The mass consisted of smooth, thin-walled cysts containing light yellow fluid in the lumen. The largest cyst was $5.5 \mathrm{~cm}$ in diameter. Histopathological examination revealed that the cystic structures were locally lined by stratified cuboidal epithelium and locally lined by hobnail cells (Figure 3). Immunohistochemically, all the epithelial cells lining the cystic structures stained positive for cytokeratin 19 and negative for CD10, carbonic anhydrase-9, and vimentin. While the stromal component stained positive for progesterone receptor and stained focally positive for estrogen receptor and smooth muscle actin, no staining was observed for desmin. With these histomorphologic results, the patient was diagnosed

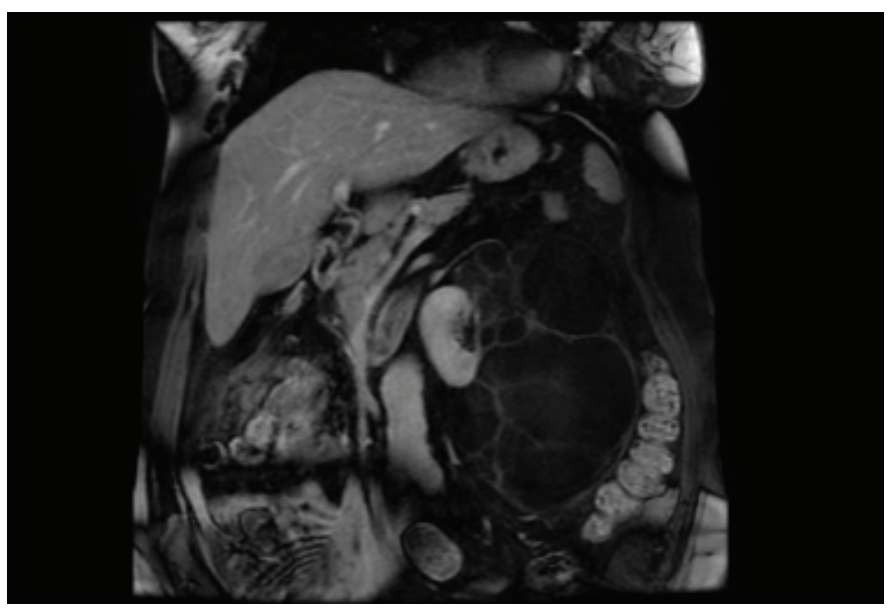

Figure 1. Multiple thick and some irregular septae of the multilocular septate cyst are visualized. Contrast uptake is visualized in the septae of the multilocular cystic mass consistent with Bosniak 3 on coronal contrastenhanced T1-weighted images with MEST according to the 2016 World Health Organization classification of urogenital tumors. The appearance of the patient's incision scar one month after the surgery is shown in Figure 4.

\section{Discussion}

Cystic nephroma accounts for approximately $1-2 \%$ of all renal masses (4). Nearly 200 cases of cystic nephroma have been presented in the literature over 125 years since its first description until today (7).

Cystic nephroma shows bimodal age distribution, two-thirds of patients are males in the first two years of childhood; a second increase in incidence is seen over 30 years of age with female predominance. No cystic formations are found in other organs (4). Likewise, our patient's imaging revealed no cystic formation in other intraabdominal organs.

Although the etiologic factors are not clearly known, basically, the congenital factors are considered in childhood, whereas the acquired factors are considered to be preliminary in postmenopausal women (8). Steele et al. (9) described the similarities between tumor stroma and overian-stroma and they suggested that cystic nephroma may develop as a result of atypical localization of the Mullerian type tissue in the kidney.

In a review article by Granja et al. (10), the most common initial findings were according to the frequency order have been reported as a palpable mass (35.2\%), incidental imaging

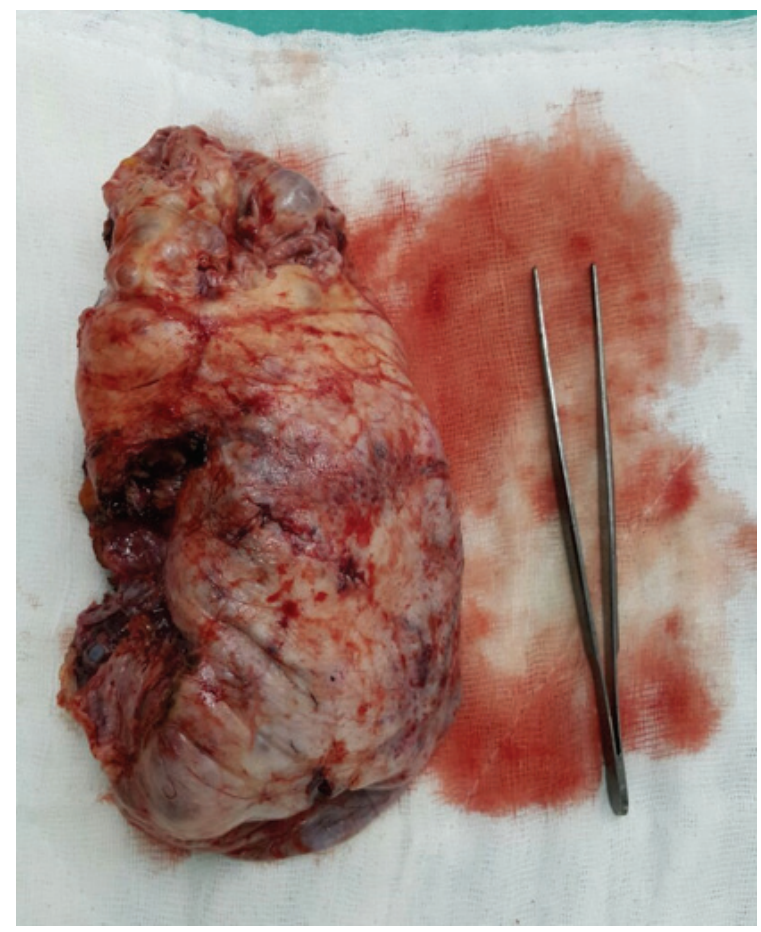

Figure 2. Macroscopic view of the mass in the operating room after the excision 


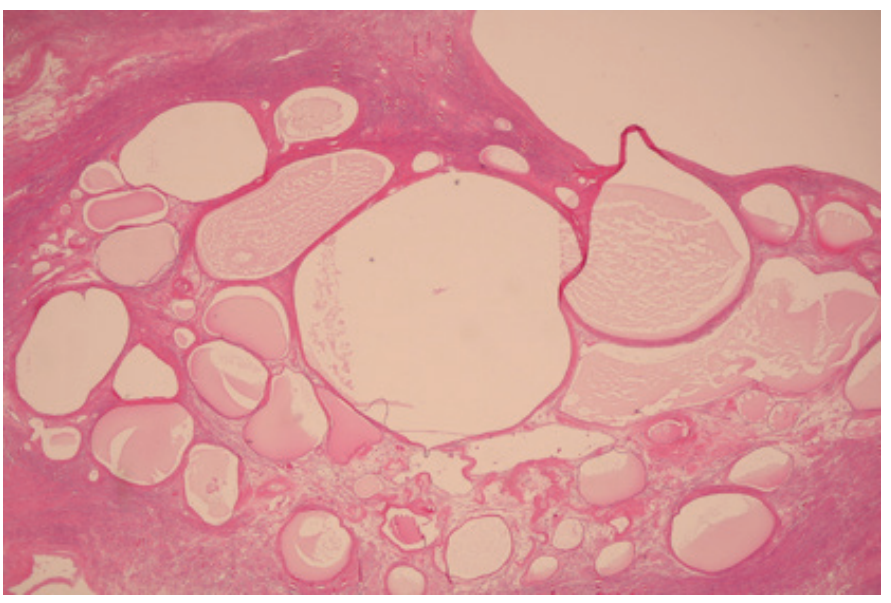

Figure 3. Multiple cysts lined by stratified epithelium embedded in the hypocellular fibrous stroma $(\mathrm{H} \& \mathrm{E} ; \times 100)$

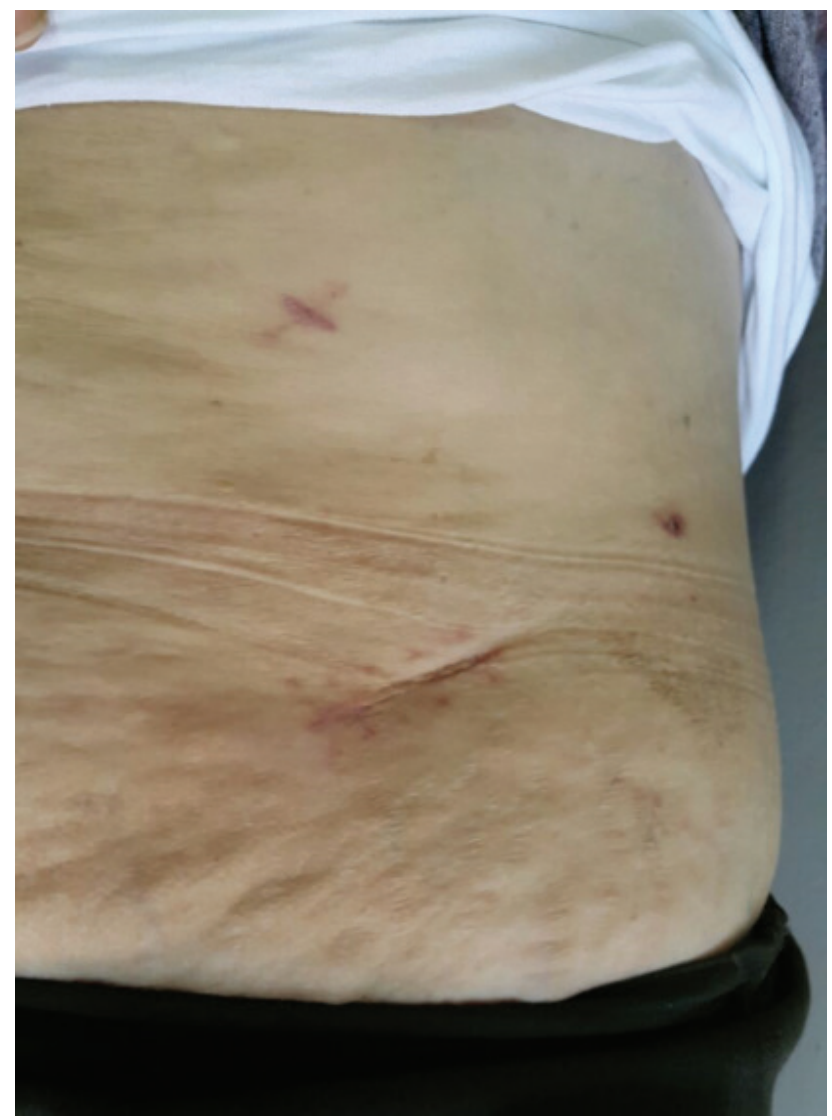

Figure 4. The appearance of the patient's incision scar one month after the surgery

finding (23.2\%), abdominal pain (18.7\%), hematuria (7.1\%), non-specific symptoms (5.2\%), and a palpable mass with hypertension (3.9\%). In the same study, the authors have reported that the most common clinical presentation of cystic nephroma was unilateral solitary mass and that the median size of mass was $73 \mathrm{~mm}$ in patients aged 11 and older. Likewise, the symptoms of lateral pain, hematuria and hypertension were present in our patient during the clinical admission, but the largest diameter of the mass was found to be considerably higher than the median values reported in the literature.

Even if the multilocular characteristic of cystic nephroma can be revealed by imaging techniques, it is very difficult to distinguish Bosniak type 2 and 3 cysts. They are both visualized as cystic lesions with numerous septae on computed tomography, and sometimes calcification may be visualized on the cyst wall (7). Likewise, while a multilocular macroscopic appearance and findings consistent with calcification on the cyst wall were detected on the dynamic magnetic resonance imaging of our patient, it was demonstrated that the cysts were not related to each other and to the collecting system.

Although biopsy is not a routine approach in Bosniak category 3 cystic masses (11), the frequency of partial nephrectomy would be increased by preoperative biopsy or frozen section biopsy peroperatively, especially in case of suspected cystic nephroma. We considered cystic renal cell carcinoma (RCC) for the prediagnosis, so we did not perform a pre-operative biopsy. Further studies in the field of radiology may increase the prevalence of cystic nephroma in the pre-operative period and may assist urologists in managing the treatment.

The diagnostic criteria of cystic nephroma has been described by Powell as being unilateral, multilocular, absence of connection between the renal pelvis and cyst, absence of connection between cysts, presence of epithelium determining the border between cysts, absence of renal structure in cyst, and presence of intact renal tissue if present (12).

The differential diagnosis of cystic tumors includes nonneoplastic cystic renal diseases, multilocular cystic RCC, sarcomatoid RCC and nephroblastoma. In multilocular cystic $\mathrm{RCC}$, clear cell conglomerations are found on the cyst wall and blastema is found in nephroblastoma. Cystic nephroma and MESTs of the kidney are benign lesions and show similar clinical, morphological and immunohistochemical characteristics. Jevremovic et al. (13) reported cystic nephroma and MEST as a single entity with varying stroma/cyst ratio. The main difference between these two entities is the rate of solid formation and the cellular content of stroma. While diffuse and thin-walled cysts are observed in cystic nephroma, MEST is a more solid tumor formation including relatively thicker-walled cysts with partial cystic formations (13).

Surgical resection provides a curative treatment. Sharma et al. (14) reported that they successfully treated a 99x82x81 mm cystic nephroma with left kidney lower pole localization by open partial nephrectomy. Sawant et al. (15) published their surgical techniques in a case which they treated the largest cystic nephroma reported in the literature $(31 \times 19 \times 19.6 \mathrm{~cm} ; 5.5$ $\mathrm{kg}$ ) by radical nephrectomy with a thoracoabdominal incision.

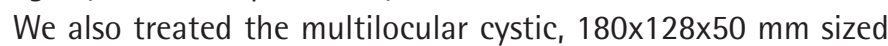


mass, which was originated from the middle-lower pole of the left kidney, by laparoscopic partial nephrectomy with zero ischemia since it did not show adjacency to major vascular structures and had an exophytic characteristic. To the best of our knowledge, the largest cystic nephroma case underwent laparoscopic nephron-sparing surgery in the literature was our patient.

The current European Association of Urology guideline on RCC recommends performing nephron-sparing surgery in localized T1-T2 stage disease, independent of the surgical technique. It is reported that partial nephrectomy is also the best treatment approach for T2 stage tumors in suitable patients, although partial nephrectomy is primarily recommended in $\mathrm{T} 1$ stage disease. Nephron-sparing surgery has also been indicated for patients with a solitary kidney, poorly functioning contralateral kidney or any pathology in the contralateral kidney and a disease causing chronic, vascular damage such as hypertension and diabetes mellitus is present (11). In our case, multilocular cystic RCC was also present among our differential diagnoses, we deemed appropriate to perform laparoscopic nephron-sparing surgery because of the additional comorbidities mentioned above, although stage $\mathrm{T} 2 \mathrm{~b}$ was revealed by imaging techniques.

\section{Conclusion}

Cystic nephroma is a rare benign tumour of the kidney; its etiology is not clearly known, and it is often incidentally diagnosed due to non-specific symptoms. It is usually possible to make the definitive diagnosis only with histopathological examination. Although biopsy is not a routine approach in the preoperative period, the diagnosis can be confirmed by taking a biopsy in cases with a high probability of cystic nephroma.

When a renal mass including multiple cystic formations is visualized on radiological imaging, the clinician should consider cystic nephroma for differential diagnosis.

Laparoscopic nephron-sparing surgery is one of the surgical treatment options that can be performed by experienced surgeons in suitable cases for the treatment of cystic nephroma regardless of the size of the mass since it has a lower morbidity rate compared to open surgery.

\section{Ethics}

Informed Consent: Written informed consent was obtained from patient who participated.

Peer-review: Externally peer-reviewed.

\section{Authorship Contributions}

Surgical and Medical Practices: U.Y., N.K., H.A.A., S.B.K., C.T.B., Concept: N.K., Design: N.K., H.A.A., Data Collection and/or Processing: N.K., S.B.K., C.T.B., Analysis and/or Interpretation: M.G.T., Literature Research: N.K., H.A.A., Writing: N.K.

Conflict of Interest: No conflict of interest was declared by the authors.

Financial Disclosure: None.

\section{References}

1. Srigley JR, Delahunt B, Eble JN, Egevad L, Epstein Jl, Grignon D, Hes 0 , Moch H, Montironi R, Tickoo SK, Zhou M, Argani P; ISUP Renal Tumor Panel. The International Society of Urological Pathology (ISUP) Vancouver classification of renal neoplasia. Am J Surg Pathol 2013;37:1469-1489.

2. Gallo GE, Penchansky L. Cystic nephroma. Cancer 1977;39:1322-1327.

3. Edmunds W. Cystic adenoma of the kidney. Trans Pathol Soc Lond 1892;43:89-90.

4. Dell'Atti L. An unusual presentation of cystic nephroma in an adult man. Rare Tumours 2015;7:5860.

5. Michal $M, A \min M B$, Delahunt $B$, et al. Mixed epithelial and stromal tumor family. In: Moch H, Humphrey PA, Ulbright TM, et al, eds. WHO Classification of Tumours of the Urinary System and Male Genital Organs. Lyon, France: IARC; 2016:70-71.

6. Srigley JR, Delahunt B, Eble JN, Egevad L, Epstein JI, Grignon D, Hes O, Moch H, Montironi R, Tickoo SK, Zhou M, Argani P; ISUP Renal Tumor Panel.The International Society of Urological Pathology (ISUP) Vancouver Classification of Renal Neoplasia. Am J Surg Pathol 2013;37:1469-1489.

7. Wilkinson C, Palit V, Bardapure M, Thomas J, Browning AJ, Gill K, Biyani CS. Adult multilocular cystic nephroma: Report of six cases with clinical, radiopathologic correlation and review of literature. Urol Ann 2013;5:1317.

8. Wani B, Kolte G, Rathod V, Banode P, Bhole A. Asymptomatic infantile cystic nephroma: a diagnostic dilemma. Indian J Surg 2012;74:501.

9. Steele R, Daroca Jr PJ, Hill S, Reed RJ, Thomas R. Multilocular renal cyst (cystic nephroma) with Mullerian-like stroma. Urology 1994;43:549-553.

10. Granja M, O'Brien A, Trujillo S, Mancera J, Aguirre D. Multilocular cystic nephroma: A systematic literature review of the radiologic and clinical findings. Roentgenology 2015;205:1188-1193.

11. Ljungberg B, Albiges L, Bensalah $K$, Bex A, Giles RH, Hora M, Kuczyk MA, Lam T, Marconi L, Merseburger AS, Powles T, Staehler M, Volpe A. Guidelines on Renal Cell Carcinoma, EAU Guidelines, 2017.

12. Powell T, Shackman $\mathrm{R}$, Johnson HD. Multilocular cysts of the kidney. $\mathrm{Br} J$ Urol 1951;23:142-152.

13. Jevremovic D, Lager DJ, Lewin M. Cystic nephroma (multilocular cyst) and mixed epithelial and stromal tumor of the kidney: A spectrum of the same entity? Ann Diagn Pathol 2006;10:77-82.

14. Sharma A, Andankar M, Pathak H. A rare presentation of cystic nephroma in a young adult. Asian J Urol 2017;4:128-130.

15. Sawant AS, Savalia AJ, Pawar P, Narwade S, Chaudhari R. A Case Report of Largest Documented Multilocular Cystic Nephroma Removed by Thoracoabdominal Approach. J Clin Diagn Res 2017;11:10-12. 